\title{
A review of 17 years of application of partnership care model on the consequences of chronic diseases: Describing and assessing the quality of the methodology of papers
}

\author{
Farshid Rahimi-Bashar ${ }^{1}$, Reza Norouzadeh², Amir Vahedian-Azimi*3 (D) \\ Received: 31 Jan 2019 \\ Published: 18 Feb 2020
}

\section{Abstract}

Background: Regarding the widespread prevalence of chronic diseases, nurses need to understand the choices, priorities, and abilities of patients in reality, their communication, and the social context in order to play their professional role and responsibility. This review study was conducted with two purposes: determining the effect of partnership-care-model (PCM) on the outcomes of chronic diseases, and describing and assessing the quality of methodology of published papers in the field.

Methods: The systematic review was conducted from inception to the year 2019. A systematic search was conducted using PRISMA guidelines to retrieve all national and international PCM studies. To assess the quality of the methodology of studies, four instruments were used, including JADAD, Consort, New Castle-Ottawa, and Cochrane.

Results: In the initial search, 11509 papers were retrieved, which according to the PRISMA guidelines, 23 relevant papers remained. The results of the reviewed papers indicated the effectiveness of the PCM. Describing and assessing the quality of the methodology of published papers of PCM was at an acceptable level. The final papers were classified and reviewed according to the authors, year, sampling characteristics, data collection methods, and final PCM conclusion.

Conclusion: According to the review of the studies and their effectiveness in the different outcomes, also, the acceptable quality of the methodology of published papers, it can be concluded that the PCM is an effective, context-based, simple, efficient, and reliable model and has the ability to be used in promoting and improving the various dimensions of chronic diseases.

Keywords: Chronic disease, Cochrane, Consort, Methodology of paper, New-castle-Ottawa, Partnership Care Model, Review study

Conflicts of Interest: None declared

Funding: None

*This work has been published under CC BY-NC-SA 1.0 license.

Copyright $\odot$ Iran University of Medical Sciences

Cite this article as: Rahimi-Bashar F, Norouzadeh R, Vahedian-Azimi A. A review of 17 years of application of partnership care model on the consequences of chronic diseases: Describing and assessing the quality of the methodology of papers. Med J Islam Repub Iran. 2020 (18 Feb);34:7. https://doi.org/10.47176/mjiri.34.7

\section{Introduction}

Technological advancements, renewal of communities, increased life expectancy, changes in lifestyle, and incli- nation for inappropriate habits have predisposed to the high prevalence of chronic diseases (1). These conditions
Corresponding author: Dr Amir Vahedian-Azimi, amirvahedian@bmsu.ac.ir

1. Department of Anesthesiology and Critical Care, School of Medicine, Hamadan University of Medical Sciences, Hamadan, Iran

2. Department of Nursing, Faculty of Nursing and Midwifery, Shahed University, Tehran, Iran

3. Trauma Research Center, Nursing Faculty, Baqiyatallah University of Medical Sciences, Tehran, Iran $\uparrow$ What is “already known” in this topic:

An approach in which a person has accepted responsibility for their illness as a primary decision-maker has not yet been introduced for chronic diseases. The methodological quality of the published papers in the partnership care model (PCM) has not been investigated so far

$\rightarrow$ What this article adds:

Implementing a PCM will increase the participation, empowerment, and ability of patients with acute and chronic illnesses because patients will develop comprehensive knowledge and attitude about the operational aspects of their illness by implementing a PCM. The study is the first study to investigate the methodology quality of published studies of PCM. 
have most often no promising prognosis (2) leading to hospitalization of individuals (3). In the United States, one-third of individuals are afflicted with a chronic disease adding up to 75 million patients, while the disease has been controlled only in \%54 of these patients (3). Meanwhile, the studies conducted so far in Iran on chronic diseases indicate that the rate of prevalence of these conditions is greater in this country compared to other countries. This necessitates the completion of some interventional programs as most of these studies reveal that lack of compliance with the implementation of educational programs and preventive measures is the leading cause of incidence and aggravation of these disorders (4-6).

The complications of these diseases make the patients susceptible to other conditions $(7,8)$ so that one-third of these patients die during the first hour before they arrive at the hospital, and the two-thirds who survive will never recover completely and never turn to ordinary life (9-11).

Given the huge mass of evidence on the relation between lifestyle and affliction with various chronic diseases, an emphasis on adjusting lifestyle as an important factor in determining the prognosis and sequelae of these diseases is justifiably highlighted (1). Indeed, many chronic conditions are noninfectious diseases induced by some agents, the most important of which is an unhealthy lifestyle (12).

In this regard, many experts render the control and care of these patients as the main responsibility of the person and their family, and believe that individuals ought to accept the responsibility of their malady and control it on the basis of their cultural context using the most suitable method and act like healthy people in the work environment, family, and community (13). This is because many chronic conditions induce long-term psychosomatic consequences after discharge from the hospital that affect the existential nature of the individual. One of these aftereffects is mental syndromes such as various cognitive disorders after discharge from the hospital (14). Hence, chronic diseases demand an approach that is different from the dominant approach used in caring for acute conditions, i.e., one in which the individual accepts the responsibility of their own disease as the main decisionmaker and contributes to it actively in the physical, mental, and social aspects (13).

So, the approach to managing chronic diseases essentially believes in the active contribution and decisionmaking of the individual or the people involved in the issue or problem (13). In this line, the Partnership Care Model is one of the local models based on the Iranian culture and context that relies on the active contribution of the patient unit (the patient, family members, and all individuals who play a role in the health/disease process) (15).

Emergence and Processing of the Partnership Care Model: This model was developed by Eisa Mohammadi in his $\mathrm{Ph}$.D. dissertation. It was developed during a qualitative study on controlling hypertension using a grounded theory design which led to determining "ineffective care relation" as the central variable. The next part of this study conceptualized the necessity of creating a contribution for controlling disease; then, it processed the clinical model of partnership care, which was finally assessed using a randomized clinical trial (15).

The data analysis in this study demonstrated that hypertension is a common, chronic, and fatal disease. The care and control of this disorder includes observing the therapeutic and care protocol such as medicinal regiment, diet, weight loss, exercise, complementary and adjunct interventions, stress reduction, and smoking cessation. The previous studies have indicated that the efforts, programs, and various interventions have not been successful in controlling this condition, so that failure in controlling hypertension is rendered as a global challenge (15).

The data of this study further showed that, for the logical and suitable control of this disorder, the characteristics and actions of the patients ought to be prioritized over the therapeutic and pharmacological methods and/or physiopathological features of the disease in the process of disease control, though controlling the disease is the dominant paradigm in current research and interventions. These variables include "lack of compliance", "insufficient perception and lack of awareness", and "establishing an unsuccessful care relation". What display the participants' dominant behavior and their coping skills in controlling the disease are their efforts in making interrelations through ineffective ones. This process is initiated by patients turning to physicians following their exposure to symptoms. The physicians try to control the disease just through drug prescription and dietary recommendations. However, patients do not adhere to treatment due to lack of awareness and insufficient perception; so, they are rehospitalized after the incidence of complications and turn to the previous condition after controlling the side-effects by nursing care and this cycle is repeated (15).

Continuous analysis and comparison of data and analysis of the participants' actions and the associations detected among the three concepts or variables suggest that "an effective care relation" is formed between the three fundamental bases of the treatment process and disease control including the patient, the nurse, and the physician. Then, the patients' awareness, compliance, and adherence to treatment, and follow-up are improved and will be effective in decreasing complications and controlling the disorder. Thus, it is mandatory to find an appropriate mechanism to achieve this goal (15).

The continued analysis of the data in the review of the literature led to the conclusion that the concept of partnership as the fourth variable can predispose to motivation, responsibility, cooperation, and engagement of individuals in team processes so that its application in various fields improves the interpersonal relations. Consequently, the creation of a partnership was proposed as a mechanism for resolving the challenge of controlling hypertension. Considering the functions of partnership and its relation with the variables, especially with the major variable, i.e., ineffective care relation, the partnership approach can be proposed and applied as a theoretical and practical foundation for creating and developing dynamic, effective, and interactive care relations in controlling hypertension (15).

This study has presented the partnership care theory instead of self-care and nursing care. Ultimately, this study 


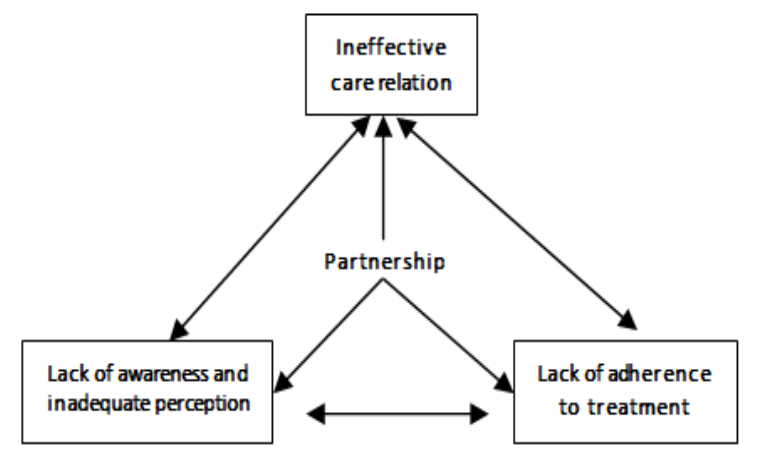

Fig. 1. The main components of Partnership Care Theory (by courtesy of Mohammadi et al., 2002 (16)

has presented three innovative issues in facing hypertension control (1) Changing the approach to the problem from microscopic and molecular examination to clientphysician and nurse interactions; (2) The complexity and persistence of this disease is not just related to its physiological nature; rather, it is related to ineffective care relation, lack of patients' adherence to treatment, and their inadequate perception of the nature and complications of the disorder; and (3) Determination and theorization of partnership in care and treatment of hypertensive (Fig. 1).

The theory above has proposed and approved the necessity of creating a dynamic, interactive, and active care relation based on the partnership element; nevertheless, it has not illustrated the how of creating and obtaining this partner care relation.

Hence, the researchers developed in another study an operational model with the following objectives through review of literature and experiences of other communities: (1) Establishing a continuous, interactive, and effective relation between the treatment and care team in the healthcare process; (2) Increasing cooperation, motivation, and responsibility among the healthcare team in the healthcare process; (3) Promotion of health level and quality care; and (4)The compliance and adherence to treatment by the patient and those contributing to the disease process.

The general goals or the resultant functions of the Partnership Care Model in hypertensive are: (1) Reducing the patient's daily average BP to less than 140/90 mmHg; (2) Diminishing the rate of cardiovascular, cerebral, renal, and ocular complications of the disease; (3) Increasing the patient's satisfaction and improving the quality of their life; (4) Decreasing the risk factors involved in aggravation of hypertension and its consequences; and (5) Reducing treatment costs. The stages of the Partnership Care Model are 1. Motivation, 2. Preparation, 3. Involvement, and 4. Evaluation.

Motivation: This is the first stage in the Partnership Care Model. Each partnership system is a voluntary system. The following steps should be taken to create motivation: (1) Complete and correct investigation and identification of the client's status and problems, and present facilities and conditions; (2) Creating the same awareness and shared perception of the concepts and goals of the care program in individuals which may vary from client to client. Although the general goal is improving and maintaining health, the meaning of improvement should be defined individually on the basis of the type of disease and its prognosis and the types of problems of each individual; (3) Familiarity of individuals and members with their roles, duties, and responsibilities in the care process; (4) Encouraging individuals, especially the patients, to get involved in the care-giving process through making them aware of the current status and also the risks and advantages of partnership care; and (5) Creating and developing reciprocal confidence between the client, physician, nurse, and other members of the healthcare team. At the end of this stage, after examining and identifying the client's status, facilities, and present conditions of the care process completely, the deficiencies, short-comings, and the identified problems should be determined in the framework of care problems and nursing diagnoses.

Preparation: This is the second stage of the Partnership Care Model aimed at creating the required background and developing the suitable program for engaging all members of partnership team including the patient, nurse, and physician since the intentions and programs will not be realized or very weak results will be obtained without responsibility and practical involvement of individuals even with the most competent persons and the best programs, facilities, and ideas. Given that healthcare measures contain a series of specialized activities, the types of activities and their relation with responsibilities and duties of individuals ought to be determined and defined on the basis of their abilities and skills to create the required background for the engagement and logical participation of all members especially clients. Moreover, the types of relations among the major elements of the healthcare process should be determined at this stage. To achieve this goal, the following measures are necessary: (1) Determining the general goal and stage objectives on the basis of problems and care diagnoses; (2) Planning continuous educational partnership visits on the basis of care problems and nursing diagnoses to prepare and coordinate individuals especially the clients for transferring information, knowledge, and specific caregiving skills; (3) Developing and explaining individuals' measures and duties and defining the reciprocal expectations; and (4) Determining the specific plan and timetable for implementing and following up the healthcare programs. During the stage of determining the plan and time-table, special attention should be paid to "planning partnership visits" and "following up of partnership visits" some characteristics of which are "teamwork", "patient-centeredness", "emphasis on education", "transmission of experiences", "creation of confidence", and "motivation and encouragement to treatment adherence and time outcome".

Involvement: When implementing any partnership program without effective management, the partnership system will gradually fade into oblivion or will be recorded in the patient's file as some sheets and pamphlets. So, a manager or coordinator ought to be selected to implement any program for any small group. The following measures are necessary for this line: (1) Determining the major head 


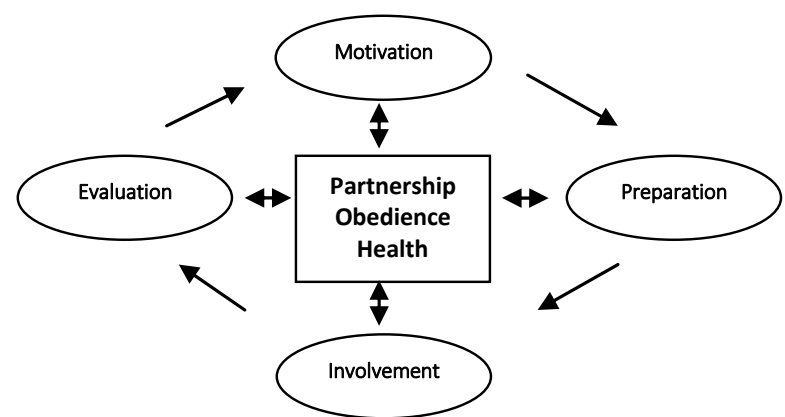

Fig. 2. The four implementation stages of the Operational Partnership Care Model (by courtesy of Mohammadi et al., 2002 (18)

of the partnership healthcare team; (2) Team agreement on transferring responsibilities and authorities to the head and cooperating with him/her; and (3) Implementing the program with the designed partnership visits by the group.

Evaluation: In the Partnership Care Model, evaluation consists of process (formative) evaluation (during the implementation of the research) and summative evaluation (final), which will be implementable on the basis of the goals set in the second stage (Fig. 2). Therefore, the researchers speculate that engaging the patient unit on the basis of involvement of family members in solving a problem may serve as an effective step to help the patients play their appropriate role to improve their own status. Consequently, nurses should recognize the patients' options, needs, and abilities in reality, and perceive their communications and social context to fulfill their professional role and duty. They should also acquire experience and insight in this field in a comprehensive framework to provide nursing care on the basis of a powerful thought (17).

This operational model was first developed on hypertensives by a researcher in a randomized clinical trial (18); then, another researcher tested and validated it on other patients with a chronic disease. Given the wide prevalence of various types of chronic disorders, the present researchers conducted a study entitled: "A review of 16 years of application of Partnership Care Model on the consequences of chronic diseases: describing and assessing the quality of the methodology of papers" aimed at (1) Determining the effect of Partnership Care Model on the consequences of chronic disorders, and (2) Describing and assessing the quality of methodology section of the published papers.

\section{Methods}

This systematic review was conducted up to December 25, 2019. A systematic search was carried out using PRISMA guideline for retrieving published and unpublished (gray literature) studies relating to Partnership Care Model (19). All methodological steps of the study were done by three highly experienced researchers (First and second author along with model designer). The final agreement between the three evaluating researchers was assessed through Kendall's coefficient of agreement $(\mathrm{r}=0.92 ; \mathrm{p}<0.001)$. The study population was all the Iranian and foreign papers that had used the Partnership Care Model.
The search was carried out in the Persian Scientific Information Database (SID), MagIran, Iran Medex, and Irandoc and also in the English databases, including Scopus, Web of Science, PubMed, Science Direct, and Proquest. The Google search engine was used in English and Persian to enrich the repertoire of retrieved articles since it is the origin of the Partnership Care Model for the Iranian patients' population. To cover all the pertinent papers, no time or language limitations were considered. The phrase "Partnership model" was used to search in the Persian databases. Also, the phrases "Partnership care", "Participatory caring", "Participatory Care", Collaborative caring", "Collaborative Care", and "Partnership caring" were used in the titles, abstracts, and keywords. To increase the richness of the retrieved papers, manual search was conducted in addition to database search to find the unpublished papers, theses, and dissertations (gray literatures) in Tehran University of Medical Sciences, Iran University of Medical Sciences, Shahid Beheshti University of Medical Sciences, University of Well-being and Rehabilitative Sciences, Tarbiat Modares University, Mashhad University of Medical Sciences, Tabriz University of Medical Sciences, Isfahan University of Medical Sciences, Shiraz University of Medical Sciences, and Yazd Shahid Sadoughi University of Medical Sciences. The selection of the sites for the manual search was done on the basis of the researchers' ability shown in Figure 1 as "Other". Moreover, in order to increase the richness of the retrieved articles, in addition to the electronic search of the mentioned databases, the researchers searched the dissertation system of the medical universities of the country to the address thesis.reserch.ac.ir; and internal theses that were consistent with the aims and criteria of the present study were included. External theses were searched and studied in the ProQuest database. The "References" of all papers were also searched to ensure of retrieval of all possible papers (Fig. 1). Endnote (Thomson Reuters, X7.5, Bld 9325) was used to organize the information. For gray literature, since full-text studies were evaluated as quality and studies such as conferences did not include essentials methodological points, they were not included in the analysis. For the IRCT database, the studies in this database were abstracts only and the published article was included in the study.

The keywords used in the said databases included: Scopus: TITLE-ABS-KEY ( "Participatory Care" OR "Participatory Caring" OR "Partnership care" OR "Partnership caring" OR "Collaborative care" OR "Collaborative caring"); PubMed: ("Participatory Care" [Title/Abstract] OR "Participatory Caring" [Title/Abstract] OR "Partnership care" [Title/Abstract] OR "Partnership caring" [Title/Abstract] OR "Collaborative care" [Title/Abstract] OR "Collaborative caring"[Title/Abstract]); Web of Science: TOPIC: ("Participatory Care" OR "Participatory Caring" OR "Partnership care" OR "Partnership caring" OR "Collaborative care" OR "Collaborative caring"); Proquest: ab ("Participatory Care" OR "Participatory Caring" OR "Partnership care" OR "Partnership caring" OR "Collaborative care" OR "Collaborative caring" ); Science Direct: TITLE-ABSTR-KEY ("Partici- 
patory Care" OR "Participatory Caring" OR "Partnership care" OR "Partnership caring" OR "Collaborative care" OR "Collaborative caring"); Google Scholar: ("Participatory Care" OR "Participatory Caring" OR "Partnership care" OR "Partnership caring" OR "Collaborative care" OR "Collaborative caring").

Regarding the Google scholar search engine, the English search resulted in 17300 papers that were irrelevant; so, to manage a purposive search and avoid unwanted deletion of papers, only the first 30 pages were surveyed.

The primary criteria of paper selection were: the use of the Partnership Care Model and the availability of the electronic or physical file of the paper. Review articles and letters-to-the-editor were excluded from the study due to the lack of use of primary data and oral presentation; also, paper posters were omitted if the main article was inaccessible or if its methodology was omitted from the paper. Having examined the retrieved papers, they were screened on the basis of inclusion criteria so that we came up with papers that observed the inclusion criteria.

The quality of finalized papers was evaluated separately by three experienced assessors (first and second authors along with model designer) who were familiar with systematic reviews. Then, the results were discussed in a common coordination session. The problematic areas were debated and the final agreement was achieved among the three assessors. The final agreement between the three evaluating researchers was assessed through Kendall's coefficient of agreement $(\mathrm{r}=0.92 ; \mathrm{p}<0.001)$. Four scales, including JADAD $(20,21)$, Cochrane Risk of Bias (22, 23), Newcastle-Ottawa (13), and the subscale checklist of Consort (21) were applied that were accessible at www.consort-statement.org. These four instruments were used for two reasons: (1) Different examination and view of each tool for the same papers, and (2) Comparison of scores obtained from different tools for the same papers.

The JADA scale includes 5 items on randomization, randomization method, blinding, blinding method, and the samples excluded from the study. Each item will receive either 0 or 1 point. The item will receive 1 point if it is reported properly and 0 if it is not reported or if it is reported improperly. The maximal score of this scale is 5 $(20,21)$.

The Cochrane Risk of Bias is a scale used for examining the rate of bias in interventional studies. In this scale, statistical bias is assessed as judgments about selection, performance, attrition, reporting, and other important cases (Other) using a Likert scale ranging from high, low, and unclear $(22,23)$.

The new version of the Consort checklist is a 25 -item inventory that includes 37 sub-items in the areas of title, abstract, introduction, methodology, results, discussion, and some information related to the paper itself. In the case of proper reporting of each item, the page number of the report of that item is recorded (21). In this assessment, only 7 out of 37 items were emphasized including (1a) Stating the phrase "randomized trial" in the title; (4a) The participants' inclusion criteria; (4b) Setting of data collection; (5) The type of intervention in each group so that it could be replicated by other people; (6a) Full explanation of the tools required for the outcomes of the study and the time of their completion; (17a) Statement of the results of the study along with a report on the effect size and accuracy for each of the outcomes of the study; (23) The IRCT code and the place of registration of the clinical trial. In addition to the separate investigation of the 7 items explained above, the number of the items reported as appropriate will be reported as the total score of the scale ranging from 0 to 7 .

The Newcastle-Ottawa scale examines the papers in terms of "selection process" (4 stars), "comparability" (2 stars), and "outcome" (3 stars). On the basis of this scale, the papers were scored from 0 (the weakest) to 9 (the strongest). In this scale, each star represents 1 point (13) (Table 1).

Descriptive statistics of frequency (percentage) and mean (SD) were used to describe and compare the scales of paper quality assessment. Spearman correlation coefficient was used to determine the correlation between the scores of assessment scales. Kruskal-Wallis and U MannWhitney tests were used to examine the difference in the scores of the three assessment scales. The subgroup analysis of the studies was done with Kruskal-Wallis and U Mann-Whitney test considering the mean scores of the three assessment scales on the year of the study, the presence of the model developer in the studies, interpersonal, inter-university, and international cooperation, and the corresponding author's place of residence. The data were analyzed with SPSS and Figure 3 was plotted with GraphPad. Kendall agreement coefficient was used to investigate the assessors' agreement on the scores obtained from the four scales of JADAD, Consort, Cochrane, and Newcastle-Ottawa $(\mathrm{p}<0.05)$.

\section{Results}

A total of 11509 papers were retrieved in the initial search, which was reduced to 23 using the PRISMA screening guide (Fig. 1). The 23 remaining papers belonged to the following databases: SID, 8 papers, Irandoc, 10 papers, Proquest, 1 paper, Web of Science, 1 paper, and Scopus, 3 papers. It should be pointed out that Mohammadi et al. (2011) published a study in English aimed at determining the effect of Partnership Care Model on the life quality and metabolic control of adult diabetics; this study was not found in the mentioned databases at the time of electronic search (24) and was, hence, excluded

Table 1. Scoring algorithm of Newcastle-Ottawa scale for investigating study bias

\begin{tabular}{lccc}
\hline Quality rating & Selection domain & Comparability domain & Outcome domain \\
\hline Good & $\geq 3$ & $\geq 2$ & $\geq 2$ \\
Fair & 2 & $\geq 1$ & $\geq 2$ \\
Poor & $0-1$ & 0 & $0-1$ \\
\hline
\end{tabular}




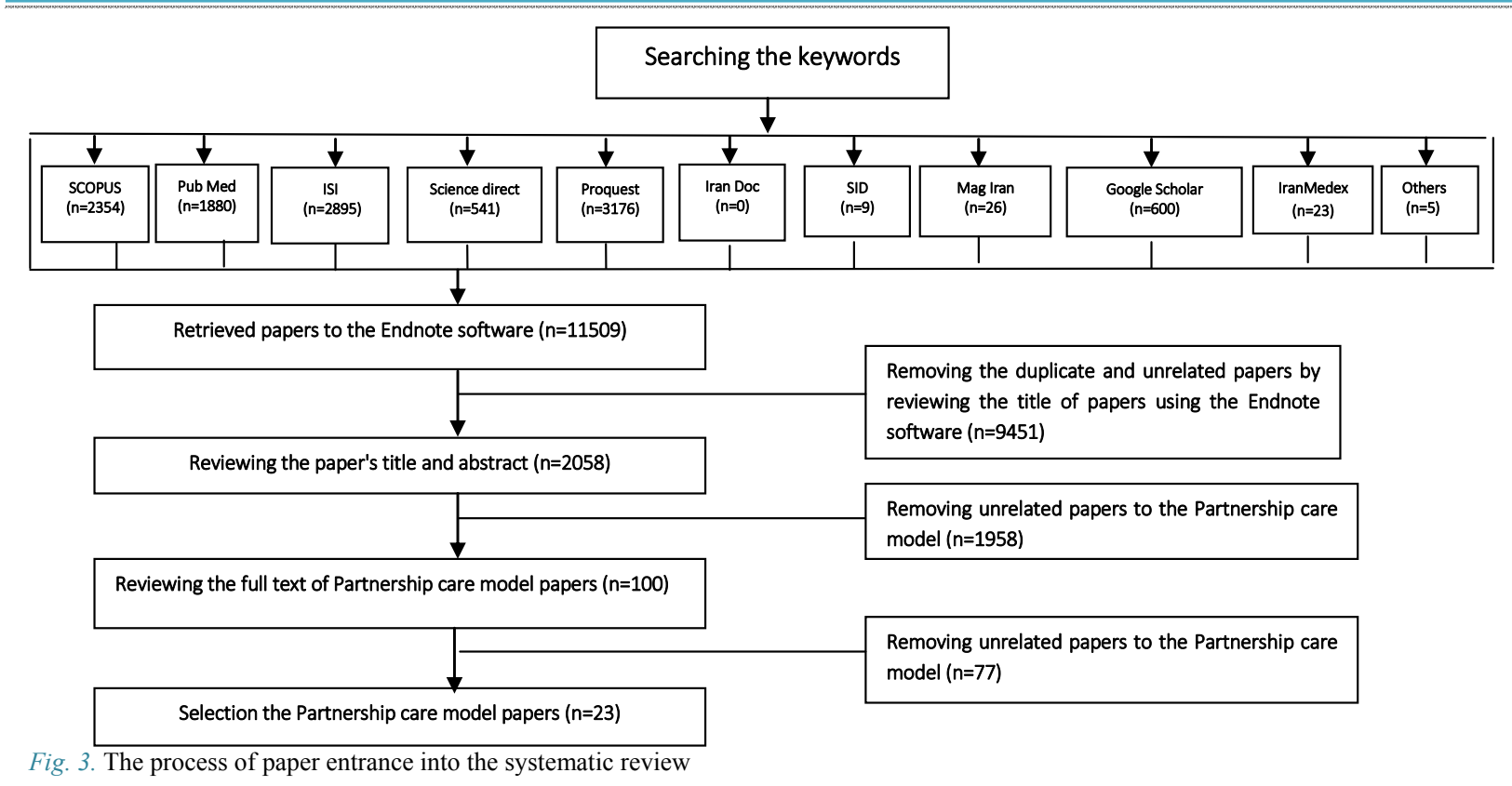

from our systematic review. The finalized papers were reviewed and classified in terms of authors, year of the study, type of research and number of groups under study, purpose of the study, sampling method, sample characteristics in terms of number and type of diseases, data collection method, and final outcome of model implementation (Table 2).

The Primary Descriptive Information of Partnership Care Model Studies: Of 23 studies conducted, 14 were two-group clinical trials, 8 were two-group quasiexperimental studies, and 1 was a single group quasiexperimental study. The studies by Khoshab et al. (25), Borhani et al. (26), Kashaninia et al. (27), and Zinati et al. (28) were single research each, resulting in two published papers. Regarding the quasi-experimental studies, an investigation of the type and methodology of the study indicated that these studies were, in fact, clinical trials; however, clinical trials were not as strong as quasiexperimental designs at the time of publication of the paper or the authors originally reported the paper in this format; maybe the design of the study has been modified during the review process. The year of publication of papers ranged from 2006 (the first paper published on model development) (28) to 2017 (Shamsi et al.) (29), Borji \& Motaghi (30), and Zare' et al. (31). Regarding the language of publication, most studies were published in Persian except Sajjadi et al. (32), Shamsi et al. (29), Mohammadi et al. $(18,33)$, and Hassanali et al. (34) which were published in English. Regarding sampling method, all 22 studies except one (Ghavidel et al.) (35) used the nonprobability convenient sampling method, census sampling, or purposive sampling method due to the nature of the study in the first stage and random assignment in the second stage. Though some authors have referred to purposive sampling, this method has been used more in qualitative studies than in quantitative ones (36) (Table 2). Moreover, regarding the journals that had published partnership care model papers, a wide spectrum of 20 Iranian and foreign journals with various indexing including scientific, scientific-research, Scopus, PubMed, and ISI had published these studies. The number of papers published in each journal is given in front of the journal's name. The Persian journals were: Journal of Babol University of Medical Sciences (1), Journal of Shahr-e-Kord University of Medical Sciences (1), Evidence-based Care Quarterly (2), Journal of ICU Nursing (1), Journal of Psychological Nursing (2), Iranian Journal of Nursing (1), InternalSurgical Nursing Quarterly (2), Journal of Qom University of Medical Sciences, Journal of Military Care Sciences (1), Journal of Prevention and Health (1), Rehabilitative Research in Nursing (2), Journal of Sabzevar University of Medical Sciences (1), Clinical Journal of Nursing \& Midwifery (1), Scientific Journal of Hamadan School of Nursing \& Midwifery (1), and Ibn-e Sina (Avicenna) Scientific Journal/NAJA Health \& Treatment Office (1). The English Journals were:

Scholarly Quarterly of the Horizon of Medical Sciences (1), Depression Research and Treatment (1), Applied Nursing Research (1), International Journal of Nursing Practice (1), and Journal of Diabetes and Metabolism (1).

Regarding questionnaires, specialized disease-based questionnaires were used in many cases that made patient assessment more realistic and transparent. Some of these questionnaires included: Spielberger's Situational Anxiety Measurement Questionnaire, Child's General Life Quality Questionnaire (Parents \& Child Report), Beck's Anxiety and Depression Questionnaire, Cardiac Patients' Life Quality Questionnaire, the 21-item Anxiety, Stress, and Depression Questionnaire, Adult Asthmatic Patients' Life Quality Questionnaire, Fatigue Severity Questionnaire, LifeStyle Questionnaire, Nottingham Life Quality Questionnaire, Perceived Social Support Questionnaire, General Self-efficacy Questionnaire, Beck's Self-image Questionnaire, the 42-item Depression, Anxiety, and Stress Questionnaire, the second version of Beck's Depression Questionnaire, SF-36 Life Quality Questionnaire, Peters- 
burg Sleep Quality Questionnaire, Spielberger's Overt \& Covert Anxiety Questionnaire, the 28-item Mental Health Questionnaire, and Daily Activities Questionnaire (Table 2).

Regarding the study population, the Partnership Care
Model has been used in senescent patients (30), adults (41-45, 25-26, 35, 18, 39, 31-33, \& 47), teenagers (27-29, $34,38, \& 40)$, and young children and infants $(37,46)$. Yet, the emphasis in the young children and infant population has been on parents. Finally, regarding type of diseas-

\begin{tabular}{|c|c|c|c|c|c|c|}
\hline Author (Year) & $\begin{array}{c}\text { Research } \\
\text { design }\end{array}$ & $\begin{array}{l}\text { Dependent } \\
\text { variable }\end{array}$ & $\begin{array}{l}\text { Sampling } \\
\text { method }\end{array}$ & $\begin{array}{c}\text { Sample } \\
\text { specifications }\end{array}$ & $\begin{array}{l}\text { Data collection } \\
\text { Questionnaire }\end{array}$ & Conclusion \\
\hline $\begin{array}{l}\text { Alijany } \\
1391(37)\end{array}$ & $\begin{array}{l}\text { Two groups } \\
\text { experimental }\end{array}$ & $\begin{array}{l}\text { Quality of life } \\
\text { of school age } \\
\text { children }\end{array}$ & $\begin{array}{l}\text { Convenience } \\
\text { and random } \\
\text { allocation }\end{array}$ & $\begin{array}{l}72 \text { children with } \\
\text { thalassemia } \\
\text { major }\end{array}$ & $\begin{array}{l}\text { General quality of } \\
\text { child's life }\end{array}$ & $\begin{array}{l}\text { TMean scores of quality of life in all } \\
\text { dimensions (Parental and child re- } \\
\text { porting), except for the parental } \\
\text { physical function in the intervention } \\
\text { compared to the control group }\end{array}$ \\
\hline $\begin{array}{l}\text { Khoshab } \\
1391(25)\end{array}$ & $\begin{array}{l}\text { Two groups } \\
\text { clinical trial }\end{array}$ & $\begin{array}{l}\text { Depression } \\
\text { and anxiety }\end{array}$ & $\begin{array}{l}\text { Convenience } \\
\text { and random } \\
\text { allocation }\end{array}$ & $\begin{array}{l}90 \text { patients with } \\
\text { heart failure }\end{array}$ & $\begin{array}{l}\text { Beck's anxiety } \\
\text { and depression }\end{array}$ & $\begin{array}{l}\downarrow \text { Mean scores of anxiety and depres- } \\
\text { sion in the intervention compared to } \\
\text { the control group }\end{array}$ \\
\hline $\begin{array}{l}\text { Borhani } \\
1391(26)\end{array}$ & $\begin{array}{l}\text { Two groups } \\
\text { clinical trial }\end{array}$ & Quality of life & $\begin{array}{l}\text { Convenience } \\
\text { and random } \\
\text { allocation }\end{array}$ & $\begin{array}{l}90 \text { patients with } \\
\text { heart failure }\end{array}$ & $\begin{array}{l}\text { Heart failure } \\
\text { quality of life }\end{array}$ & $\begin{array}{l}\text { Ooverall mean score of quality of life } \\
\text { and three dimensions physical, psy- } \\
\text { chological, and social in the interven- } \\
\text { tion compared to the control group }\end{array}$ \\
\hline $\begin{array}{l}\text { Parviniannasab } \\
1392 \text { (38) }\end{array}$ & $\begin{array}{l}\text { Two groups } \\
\text { semi- } \\
\text { experimental }\end{array}$ & Depression & $\begin{array}{l}\text { Convenience } \\
\text { and random } \\
\text { allocation }\end{array}$ & $\begin{array}{l}60 \text { teens with } \\
\text { thalassemia } \\
\text { major }\end{array}$ & $\begin{array}{l}\text { Depression, anxi- } \\
\text { ety, and stress } 21\end{array}$ & $\begin{array}{l}\downarrow \text { Mean depression score in the inter- } \\
\text { vention compared to the control } \\
\text { group }\end{array}$ \\
\hline $\begin{array}{l}\text { Daneshi } \\
1393 \text { (39) }\end{array}$ & $\begin{array}{l}\text { Two groups } \\
\text { clinical trial }\end{array}$ & Quality of life & $\begin{array}{l}\text { Convenience } \\
\text { and random } \\
\text { allocation }\end{array}$ & $\begin{array}{l}80 \text { adult with } \\
\text { asthma }\end{array}$ & $\begin{array}{l}\text { Asthmatic adult } \\
\text { quality of life }\end{array}$ & $\begin{array}{l}\text { Toverall mean score of quality of life } \\
\text { and four dimensions physical, psy- } \\
\text { chological, social, and living envi- } \\
\text { ronment in the intervention compared } \\
\text { to the control group }\end{array}$ \\
\hline $\begin{array}{l}\text { Hassanali } \\
1392(40)\end{array}$ & $\begin{array}{l}\text { Two groups } \\
\text { quasi- } \\
\text { experimental }\end{array}$ & $\begin{array}{c}\text { Metabolic } \\
\text { control of } \\
\text { diabetic teens }\end{array}$ & $\begin{array}{l}\text { The census } \\
\text { and random } \\
\text { allocation }\end{array}$ & $\begin{array}{l}40 \text { diabetic } \\
\text { teens }\end{array}$ & $\begin{array}{l}\text { Diabetes control, } \\
\text { Glycosylated } \\
\text { hemoglobin, and } \\
\text { insulin consump- } \\
\text { tion index }\end{array}$ & $\begin{array}{l}\text { TMean score of glycosylated hemo- } \\
\text { globin control and insulin consump- } \\
\text { tion in the intervention compared to } \\
\text { the control group }\end{array}$ \\
\hline $\begin{array}{l}\text { Mamene } \\
1393(41)\end{array}$ & $\begin{array}{l}\text { Two groups } \\
\text { clinical trial }\end{array}$ & $\begin{array}{l}\text { Nutritional } \\
\text { behavior of } \\
\text { the family }\end{array}$ & $\begin{array}{l}\text { The census } \\
\text { and random } \\
\text { allocation }\end{array}$ & $\begin{array}{l}40 \text { family } \\
\text { members of } \\
\text { patients with } \\
\text { type II diabetics }\end{array}$ & Adjusted life style & $\begin{array}{l}\text { TMean score fast food consumption, } \\
\text { fruits, vegetables, cans, sweets, solid, } \\
\text { vegetable oil, sausages, heavy dinner } \\
\text { in late time in the intervention com- } \\
\text { pared to the control group }\end{array}$ \\
\hline $\begin{array}{l}\text { Lashkari } \\
1395 \text { (42) }\end{array}$ & $\begin{array}{l}\text { Two groups } \\
\text { clinical trial }\end{array}$ & Fatigue & $\begin{array}{l}\text { Purposeful } \\
\text { and random } \\
\text { allocation }\end{array}$ & $\begin{array}{l}52 \text { under hemo- } \\
\text { dialysis patients }\end{array}$ & Fatigue severity & $\begin{array}{l}\text { } \text { overall mean score of fatigue inten- } \\
\text { sity with a slight and non-significant } \\
\text { increasing in fatigue rate and reduc- } \\
\text { ing in fatigue severity in the interven- } \\
\text { tion compared to the control group }\end{array}$ \\
\hline $\begin{array}{l}\text { Zare } \\
1396(31)\end{array}$ & $\begin{array}{l}\text { Two groups } \\
\text { clinical trial }\end{array}$ & $\begin{array}{l}\text { Reducing the } \\
\text { disease com- } \\
\text { plications and } \\
\text { improve } \\
\text { quality of life }\end{array}$ & $\begin{array}{l}\text { Purposeful } \\
\text { and random } \\
\text { allocation }\end{array}$ & $\begin{array}{c}58 \text { coronary } \\
\text { patients }\end{array}$ & $\begin{array}{l}\text { Nottingham's } \\
\text { quality of life }\end{array}$ & $\begin{array}{l}\downarrow \text { Mean score of quality of life as } \\
\text { well as decreasing trend in the four } \\
\text { groups after the intervention with a } \\
\text { moderate significant effect size in the } \\
\text { intervention compared to the control } \\
\text { group }\end{array}$ \\
\hline $\begin{array}{l}\text { Borji } \\
1396 \text { (30) }\end{array}$ & $\begin{array}{l}\text { Two groups } \\
\text { clinical trial }\end{array}$ & $\begin{array}{l}\text { Social sup- } \\
\text { port and } \\
\text { public self- } \\
\text { efficacy }\end{array}$ & $\begin{array}{l}\text { Convenience } \\
\text { and random } \\
\text { allocation }\end{array}$ & $\begin{array}{l}80 \text { elderly peo- } \\
\text { ple }\end{array}$ & $\begin{array}{l}\text { Perceived social } \\
\text { support, and self- } \\
\text { efficacy }\end{array}$ & $\begin{array}{l}\text { Mean score of social support and } \\
\text { general self-efficacy in the interven- } \\
\text { tion compared to the control group }\end{array}$ \\
\hline $\begin{array}{l}\text { Sajjadi } \\
1395 \text { (32) }\end{array}$ & $\begin{array}{l}\text { Two groups } \\
\text { clinical trial }\end{array}$ & $\begin{array}{c}\text { Self- } \\
\text { conception }\end{array}$ & $\begin{array}{l}\text { Convenience } \\
\text { and random } \\
\text { allocation }\end{array}$ & $\begin{array}{l}60 \text { patients with } \\
\text { type } 2 \text { diabetes }\end{array}$ & $\begin{array}{l}\text { Beck's self- } \\
\text { reflection }\end{array}$ & $\begin{array}{l}\uparrow \text { Mean score of self-conception in } \\
\text { the intervention compared to the } \\
\text { control group }\end{array}$ \\
\hline $\begin{array}{l}\text { Rezapour } \\
1395(43)\end{array}$ & $\begin{array}{l}\text { Two groups } \\
\text { clinical trial }\end{array}$ & $\begin{array}{l}\text { Depression, } \\
\text { anxiety, and } \\
\text { stress }\end{array}$ & $\begin{array}{l}\text { Convenience } \\
\text { and random } \\
\text { allocation }\end{array}$ & $\begin{array}{l}50 \text { patients } \\
\text { undergoing } \\
\text { angioplasty }\end{array}$ & $\begin{array}{l}\text { Depression, anxi- } \\
\text { ety, and stress } 42\end{array}$ & $\begin{array}{l}\downarrow \text { Mean score of depression, anxiety, } \\
\text { and stress in the intervention com- } \\
\text { pared to the control group }\end{array}$ \\
\hline $\begin{array}{l}\text { Kashaninia } \\
1395(27)\end{array}$ & $\begin{array}{l}\text { Two groups } \\
\text { semi- } \\
\text { experimental }\end{array}$ & Depression & $\begin{array}{l}\text { Purposeful } \\
\text { and random } \\
\text { allocation }\end{array}$ & $\begin{array}{l}40 \text { teens with } \\
\text { thalassemia } \\
\text { major }\end{array}$ & $\begin{array}{l}\text { Second version of } \\
\text { beck's depression }\end{array}$ & $\begin{array}{l}\downarrow \text { Mean score of depression in the } \\
\text { intervention compared to the control } \\
\text { group }\end{array}$ \\
\hline $\begin{array}{l}\text { Zinati } \\
1394(28)\end{array}$ & $\begin{array}{l}\text { Two groups } \\
\text { semi- } \\
\text { experimental }\end{array}$ & Quality of life & $\begin{array}{l}\text { Convenience } \\
\text { and random } \\
\text { allocation }\end{array}$ & $\begin{array}{l}40 \text { teens with } \\
\text { thalassemia } \\
\text { major }\end{array}$ & $\begin{array}{c}\text { SF-36 quality of } \\
\text { life }\end{array}$ & $\begin{array}{l}\uparrow \text { Mean score of quality of life in the } \\
\text { intervention compared to the control } \\
\text { group }\end{array}$ \\
\hline $\begin{array}{l}\text { Alamdarloo } \\
1394(44)\end{array}$ & $\begin{array}{l}\text { Two groups } \\
\text { semi- } \\
\text { experimental }\end{array}$ & $\begin{array}{l}\text { Quality of } \\
\text { sleep }\end{array}$ & $\begin{array}{l}\text { Purposeful } \\
\text { and random } \\
\text { allocation }\end{array}$ & $\begin{array}{l}60 \text { undergoing } \\
\text { CABG surgery } \\
\text { patients }\end{array}$ & $\begin{array}{c}\text { Petersburg's } \\
\text { quality of sleep }\end{array}$ & $\begin{array}{l}\downarrow \text { Mean score of quality if sleep in the } \\
\text { intervention compared to the control } \\
\text { group }\end{array}$ \\
\hline $\begin{array}{l}\text { Nayyeri } \\
1394(45)\end{array}$ & $\begin{array}{l}\text { Two groups } \\
\text { clinical trial }\end{array}$ & $\begin{array}{l}\text { Quality of } \\
\text { sleep }\end{array}$ & $\begin{array}{l}\text { Convenience } \\
\text { and random } \\
\text { allocation }\end{array}$ & $\begin{array}{l}102 \text { patients } \\
\text { with heart fail- } \\
\text { ure }\end{array}$ & $\begin{array}{c}\text { Petersburg's } \\
\text { quality of sleep }\end{array}$ & $\begin{array}{l}\downarrow \text { Mean score of quality of sleep in the } \\
\text { intervention compared to the control } \\
\text { group }\end{array}$ \\
\hline
\end{tabular}




\begin{tabular}{|c|c|c|c|c|c|c|}
\hline \multicolumn{7}{|l|}{ Table 2. Ctd } \\
\hline Author (Year) & $\begin{array}{l}\text { Research } \\
\text { design }\end{array}$ & $\begin{array}{l}\text { Dependent } \\
\text { variable }\end{array}$ & $\begin{array}{l}\text { Sampling } \\
\text { method }\end{array}$ & $\begin{array}{c}\text { Sample } \\
\text { specifications }\end{array}$ & $\begin{array}{l}\text { Data collection } \\
\text { Questionnaire }\end{array}$ & Conclusion \\
\hline $\begin{array}{l}\text { Nouhi } \\
1393 \text { (46) }\end{array}$ & $\begin{array}{l}\text { Two groups } \\
\text { clinical trial }\end{array}$ & $\begin{array}{l}\text { Anxiety of } \\
\text { mothers }\end{array}$ & $\begin{array}{l}\text { Convenience } \\
\text { and random } \\
\text { allocation }\end{array}$ & $\begin{array}{l}90 \text { mothers, } \\
\text { have a child } \\
\text { with gastroin- } \\
\text { testinal infec- } \\
\quad \text { tion }\end{array}$ & $\begin{array}{l}\text { Spilberger's ap- } \\
\text { parent and hidden } \\
\text { anxiety }\end{array}$ & $\begin{array}{l}\downarrow \text { Mean score of apparent anxiety and } \\
\text { being at the moderate to high level } \\
\text { hidden anxiety in the intervention } \\
\text { compared to the control group }\end{array}$ \\
\hline $\begin{array}{l}\text { Mamene } \\
1393(47)\end{array}$ & $\begin{array}{l}\text { Two groups } \\
\text { clinical trial }\end{array}$ & $\begin{array}{l}\text { Nutritional } \\
\text { behavior }\end{array}$ & $\begin{array}{l}\text { Convenience } \\
\text { and random } \\
\text { allocation }\end{array}$ & $\begin{array}{l}40 \text { patients with } \\
\text { diabetes }\end{array}$ & $\begin{array}{l}\text { Nutritional part of } \\
\text { life style }\end{array}$ & $\begin{array}{l}\uparrow \text { Mean score of taking meals, eating } \\
\text { more than three times, taking liquid } \\
\text { oil, fruits, vegetables, and fish in the } \\
\text { intervention compared to the control } \\
\text { group }\end{array}$ \\
\hline $\begin{array}{l}\text { Ghavidel } \\
1388(35)\end{array}$ & $\begin{array}{l}\text { One group } \\
\text { semi- } \\
\text { experimental }\end{array}$ & Quality of life & The census & $\begin{array}{l}32 \text { under hemo- } \\
\text { dialysis patients }\end{array}$ & $\begin{array}{c}\text { SF-36 quality of } \\
\text { life }\end{array}$ & $\begin{array}{l}\uparrow \text { Mean score of physical dimensions } \\
\text { (physical function, physical activity } \\
\text { limitation, physical pain, and general } \\
\text { health), mental health (mental health, } \\
\text { well-being, social function, and psy- } \\
\text { chological role limitation) in the } \\
\text { intervention compared to the control } \\
\text { group }\end{array}$ \\
\hline $\begin{array}{l}\text { Shams } \\
1396(29)\end{array}$ & $\begin{array}{l}\text { Two groups } \\
\text { experimental }\end{array}$ & Mental health & $\begin{array}{l}\text { Convenience } \\
\text { and random } \\
\text { allocation }\end{array}$ & $\begin{array}{l}82 \text { teens with } \\
\text { thalassemia } \\
\text { major }\end{array}$ & General health 28 & $\begin{array}{l}\downarrow \text { Mean score of general health and its } \\
\text { subscales physical complaints, anxie- } \\
\text { ty, social dysfunction, and depression } \\
\text { in the intervention compared to the } \\
\text { control group }\end{array}$ \\
\hline $\begin{array}{l}\text { Mohammadi } \\
1395(33)\end{array}$ & $\begin{array}{l}\text { Two groups } \\
\text { clinical trial }\end{array}$ & $\begin{array}{l}\text { Activity daily } \\
\text { living }\end{array}$ & $\begin{array}{l}\text { Convenience } \\
\text { and random } \\
\text { allocation }\end{array}$ & $\begin{array}{l}104 \text { patients } \\
\text { with heart fail- } \\
\text { ure }\end{array}$ & $\begin{array}{l}\text { Lawton daily } \\
\text { activity }\end{array}$ & $\begin{array}{l}\uparrow \text { Mean score of daily activities (using } \\
\text { phone, shopping, cooking, house- } \\
\text { keeping, washing, walking in the city } \\
\text { and taking medication) in the inter- } \\
\text { vention compared to the control } \\
\text { group }\end{array}$ \\
\hline $\begin{array}{l}\text { Mohammadi } \\
1385 \text { (18) }\end{array}$ & $\begin{array}{l}\text { Two groups } \\
\text { clinical trial }\end{array}$ & $\begin{array}{l}\text { Control of } \\
\text { blood pres- } \\
\text { sure }\end{array}$ & $\begin{array}{l}\text { Convenience } \\
\text { and random } \\
\text { allocation }\end{array}$ & $\begin{array}{l}150 \text { patients } \\
\text { with hyperten- } \\
\text { sion }\end{array}$ & $\begin{array}{l}\text { SF-36 quality of } \\
\text { life, Spilberger's } \\
\text { apparent and } \\
\text { hidden anxiety, } \\
\text { and adherence to } \\
\text { treatment }\end{array}$ & $\begin{array}{l}\uparrow \text { Mean score of total quality of life } \\
\text { along with all } 8 \text { subscales, and adher- } \\
\text { ence from the treatment, and } \downarrow \text { Mean } \\
\text { score anxiety in the intervention } \\
\text { compared to the control group }\end{array}$ \\
\hline $\begin{array}{l}\text { Hassanali } \\
1395(34)\end{array}$ & $\begin{array}{l}\text { Two groups } \\
\text { quasi- } \\
\text { experimental }\end{array}$ & $\begin{array}{c}\text { Metabolic } \\
\text { control of } \\
\text { diabetic teens }\end{array}$ & $\begin{array}{l}\text { The census } \\
\text { and random } \\
\text { allocation }\end{array}$ & $\begin{array}{l}40 \text { diabetic } \\
\text { children }\end{array}$ & $\begin{array}{l}\text { Diabetes control, } \\
\text { Glycosylated } \\
\text { hemoglobin, and } \\
\text { insulin consump- } \\
\text { tion index }\end{array}$ & $\begin{array}{l}\text { } \text { Mean score glycosylated hemoglo- } \\
\text { bin control and insulin consumption } \\
\text { in the intervention compared to the } \\
\text { control group }\end{array}$ \\
\hline
\end{tabular}

es, the Partnership Care Model has been applied to thalassemia major $(37,38,27,28, \& 29)$, cardiac failure $(25,26$, $45, \& 33)$, diabetes type II $(41,32, \& 47)$, and other chronic disorders (Table 2).

Populations under Study: In the conducted studies, the intended consequences were reported in terms of the type of disease. These outcomes are displayed completely in Table 2. The most common consequences frequently occurring in diabetics, cardiovascular patients, and thalassemia patients are presented below.

Diabetics patients: Various studies had dealt with various aspects of the healthcare issues of these patients. Generally, 3 studies focused on diabetes type II $(41,32, \& 47)$ and 2 studies addressed diabetes type I $(40,34)$. Among the studies that focused on diabetes type II, the studies by Ma'maneh et al. referred to the family's nutritional behavior (41) and the patient (47) while Sajjadi et al. focused on the promotion of self-image (32). The studies by Hassanali et al. focused on metabolic control of blood sugar levels in type I diabetic patients $(40,34)$ (Table 2).

Cardiovascular Patients: Various classifications were done on cardiovascular diseases; nevertheless, all patients with heart failure, myocardial infarction, CABG patients, and angioplasty patients were grouped under the cardio- vascular category. Generally, 7 studies on cardiovascular diseases investigated the effect of the Partnership Care Model on various aspects of cardiovascular disorders. These included the study by Khoshab et al. on the rate of depression and anxiety in heart failure patients (25), the study by Borhani et al. on the life quality of heart failure patients (26), the study by Niri et al. on the life quality of heart failure patients (45), the study by Mohammadi et al. on the daily activities of heart failure patients (33), the study by Zare' et al. on reducing disease complications and improving the life quality of MI patients (31), the study by Rezapoor et al. on the severity of depression, anxiety, and stress in angioplasty patients (43), and the study by Alamdarloo et al. on the life quality of CABG patients (44) (Table 2).

Thalassemia Patients: The studies on thalassemia were carried out in three areas: children (37), teenagers $(38,27$, $28, \& 29)$, and parents of thalassemia children (37). The study by Alijany et al. focused on the quality of life of school-age children and their parents (37), the study by Parvinian et al. on teenager depression (38), the study by Kashaninia et al. on teenager depression (27), the study by Zinatinia et al. on life quality of teenagers (28), and the study by Shamsi et al. on mental health of thalassemia 
teenagers (29) (Table 2)

Assessment of Quality of Papers: The data on paper quality assessed by JADAD, Consort, Cochrane, and Newcastle-Ottawa scales were imported to Microsoft Excel 2007 and were categorized, compared, and summarized on the basis of the data presented (Tables $3 \& 4$ ). Considering the quality of the assessed papers and various outcome variables reported in each study, no metaanalysis was possible, and the results were presented as investigation of the quality of the papers. Other reasons aside from the quality of papers were: various tools used, the heterogeneous groups reported in the studies, and deficient results that could not be integrated or accumulated. The quality of papers was assessed by three separate assessors experienced in the evaluation of the quality of publications. Group sessions were held by the three assessors at the end of the assessment of each scale to check the accuracy of the performed assessments. In the case of any disparity among the three assessors, the debate continued till an agreement was achieved on the assessment scores of the four scales of JADAD $(\mathrm{p}<0.001)$, Consort $(p<0.001)$, Cochrane $(p<0.001)$ and Newcastle-Ottawa $(\mathrm{p}<0.001)$.

Description of Scores of JADAD, Consort, and Newcastle-Ottawa: The maximum score of JADAD was 5, eleven studies obtained a score of 3 , and other studies (12 stud- ies) obtained a score of less than 3 (Table 3). The maximum score of Consort was 7, two studies obtained 7, six studies obtained 6 , and the remaining 15 studies obtained scores of less than 6. Also, the maximum score of Newcastle-Ottawa was 9, and interestingly all 23 studies obtained 8 (Table 4).

Cochrane Risk of Bias: This scale examines bias in studies qualitatively in five areas at the low, high, and unclear levels. In the area (category) of creating random sequence due to selection bias, all 22 studies except one, that reported high bias, reported low-level bias. In the area (category) of random concealment from selection bias, all 23 studies had reported this category as unclear. Also, the two aspects (dimensions) of "blinding of samples" and "blinding of consequences" from the category of performance bias were reported as unclear in all studies. The status of the category of other types of bias was reported as unclear in all studies (Table 3).

The Newcastle-Ottawa Scale: The three categories of selection, comparability, and consequences were at an acceptable level in all reviewed studies. Yet, one aspect of the category of comparability that pertained to considering the intervening variables in the analysis of data of the studies was not at an acceptable level. This important point was not noticed in any of the reviewed studies (Tables 1 \& 4).

Table 3. The quality assessment of papers with JADAD and Cochrane Risk of Bias scales

$$
\text { JADAD Scale }
$$

Author (Year)

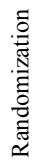

Alijany 1391 (37)

Khoshab $1391(25)$

Borhani $1391(26)$

Parviniannasab

$1392(38)$

Daneshi 1393 (39)

Hassanali 1392( 40)

Mamene 1393 (41)

Lashkari 1395 (42)

Zare $1396(31)$

Borji $1396(30)$

Sajjadi $1395(32)$

Rezapour 1395 (43)

Kashaninia $1395(27)$

Zinati 1394 (28)

Alamdarloo 1394 (44)

Nayyeri $1394(45)$

Nouhi 1393 (46)

Mamene 1393 (47)

Ghavidel 1388 (35)

Shams 1396 (29)

Mohammad

$1395(33)$

Mohammadi

1385 (18)

Hassanali 1395 (34)

\section{Cochrane Risk of Bias Scale}

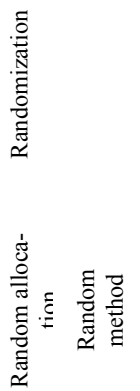

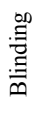

=

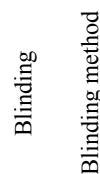

:
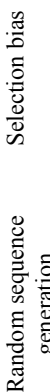

\section{Low Unclear}

Low Unclear

Low Unclear

Low

Low Unclear

Low Unclear Unclear

Low Unclear Unclear

Low Unclear Unclear

Low Unclea

Low Unclear

Low

Low

Low

Low

Low

Low

Low

High

Low

Low

Low

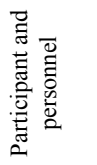

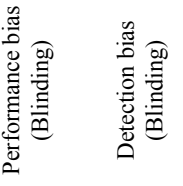

气્๊

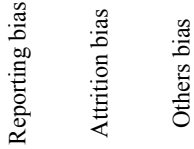

Unclear Unclear Low Low Unclear

Unclear Unclear Unclear Low Low Unclear

Unclear Unclear Unclear Low Low Unclear

Unclear Unclear Unclear Low Low Unclear

Unclear Unclear Unclear Low Low Unclear

Unclear Unclear Unclear Low Low Unclear

Unclear Unclear Unclear Low Low Unclear

Unclear Unclear Unclear Low Low Unclear

Unclear Unclear Unclear Low Low Unclear

Unclear Unclear Unclear Low Low Unclear

Unclear Unclear Unclear Low Low Unclear

Low Unclear Unclear Unclear Low Low Unclear 


\begin{tabular}{|c|c|c|c|c|c|c|c|c|c|c|c|c|c|c|c|c|c|c|}
\hline \multirow[t]{3}{*}{ Author (Year) } & \multicolumn{10}{|c|}{ Newcastle-Ottawa Scale } & \multicolumn{8}{|c|}{ CONSORT 2010 Subscale } \\
\hline & \multirow[b]{2}{*}{ 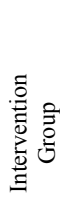 } & \multicolumn{2}{|c|}{ Selection } & \multicolumn{3}{|c|}{ Comparability } & \multirow[b]{2}{*}{ 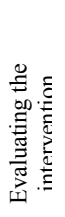 } & \multicolumn{2}{|c|}{ Outcome } & & \multirow[t]{2}{*}{$1 \mathrm{a}$} & \multirow[t]{2}{*}{$4 a$} & \multirow[t]{2}{*}{$4 \mathrm{~b}$} & \multirow[t]{2}{*}{5} & \multirow[t]{2}{*}{$6 a$} & \multirow[t]{2}{*}{$17 \mathrm{a}$} & \multirow[t]{2}{*}{23} & \multirow[b]{2}{*}{ हूँ } \\
\hline & & 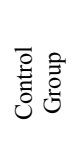 & 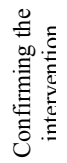 & 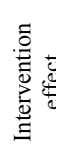 & 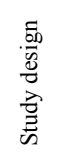 & 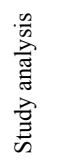 & & 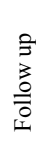 & 总 & 䒿 & & & & & & & & \\
\hline Alijany 1391 (37) & 1 & 1 & 1 & 1 & 1 & --- & 1 & 1 & 1 & 8 & --- & $1 *$ & $1 *$ & $1 *$ & $1 *$ & $1^{*}$ & --- & 5 \\
\hline Khoshab 1391 (25) & 1 & 1 & 1 & 1 & 1 & --- & 1 & 1 & 1 & 8 & --- & $1^{*}$ & $1^{*}$ & $1^{*}$ & $1^{*}$ & $1^{*}$ & --- & 5 \\
\hline Borhani 1391 (26) & 1 & 1 & 1 & 1 & 1 & --- & 1 & 1 & 1 & 8 & --- & $1^{*}$ & $1^{*}$ & $1 *$ & $1 *$ & $1^{*}$ & --- & 5 \\
\hline $\begin{array}{l}\text { Parviniannasab } \\
1392 \text { (38) }\end{array}$ & 1 & 1 & 1 & 1 & 1 & --- & 1 & 1 & 1 & 8 & --- & $1^{*}$ & $1 *$ & $1^{*}$ & $1^{*}$ & $1^{*}$ & --- & 5 \\
\hline Daneshi 1393 (39) & 1 & 1 & 1 & 1 & 1 & --- & 1 & 1 & 1 & 8 & --- & $1^{*}$ & $1 *$ & $1^{*}$ & $1 *$ & $1^{*}$ & --- & 5 \\
\hline Hassanali 1392( 40) & 1 & 1 & 1 & 1 & 1 & --- & 1 & 1 & 1 & 8 & --- & $1^{*}$ & $1^{*}$ & $1^{*}$ & $1 *$ & $1^{*}$ & --- & 5 \\
\hline Mamene 1393 (41) & 1 & 1 & 1 & 1 & 1 & --- & 1 & 1 & 1 & 8 & --- & $1 *$ & $1^{*}$ & $1 *$ & $1 *$ & $1^{*}$ & $1 *$ & 6 \\
\hline Lashkari 1395 (42) & 1 & 1 & 1 & 1 & 1 & --- & 1 & 1 & 1 & 8 & $1^{*}$ & $1^{*}$ & $1^{*}$ & $1 *$ & $1 *$ & $1^{*}$ & $1 *$ & 7 \\
\hline Zare $1396(31)$ & 1 & 1 & 1 & 1 & 1 & --- & 1 & 1 & 1 & 8 & --- & $1 *$ & $1 *$ & $1 *$ & $1 *$ & $1^{*}$ & $1 *$ & 6 \\
\hline Borji 1396 (30) & 1 & 1 & 1 & 1 & 1 & --- & 1 & 1 & 1 & 8 & -.- & $1 *$ & $1 *$ & $1 *$ & $1 *$ & $1^{*}$ & --- & 5 \\
\hline Sajjadi 1395 (32) & 1 & 1 & 1 & 1 & 1 & --- & 1 & 1 & 1 & 8 & --- & $1 *$ & $1 *$ & $1 *$ & $1 *$ & $1 *$ & $1 *$ & 6 \\
\hline Rezapour 1395 (43) & 1 & 1 & 1 & 1 & 1 & --- & 1 & 1 & 1 & 8 & --- & $1 *$ & $1 *$ & $1 *$ & $1 *$ & $1^{*}$ & $1 *$ & 6 \\
\hline Kashaninia 1395 (27) & 1 & 1 & 1 & 1 & 1 & --- & 1 & 1 & 1 & 8 & --- & $1 *$ & $1 *$ & $1 *$ & $1 *$ & $1^{*}$ & --- & 5 \\
\hline Zinati $1394(28)$ & 1 & 1 & 1 & 1 & 1 & --- & 1 & 1 & 1 & 8 & --- & $1^{*}$ & $1^{*}$ & $1^{*}$ & $1^{*}$ & $1^{*}$ & --- & 5 \\
\hline Alamdarloo 1394 (44) & 1 & 1 & 1 & 1 & 1 & --- & 1 & 1 & 1 & 8 & --- & $1^{*}$ & $1^{*}$ & $1^{*}$ & $1^{*}$ & $1^{*}$ & --- & 5 \\
\hline Nayyeri 1394 (45) & 1 & 1 & 1 & 1 & 1 & --- & 1 & 1 & 1 & 8 & --- & $1^{*}$ & $1^{*}$ & $1^{*}$ & $1^{*}$ & $1^{*}$ & $1^{*}$ & 6 \\
\hline Nouhi 1393 (46) & 1 & 1 & 1 & 1 & 1 & --- & 1 & 1 & 1 & 8 & $1^{*}$ & $1^{*}$ & $1^{*}$ & $1 *$ & $1^{*}$ & $1^{*}$ & --- & 6 \\
\hline Mamene 1393 (47) & 1 & 1 & 1 & 1 & 1 & --- & 1 & 1 & 1 & 8 & $1^{*}$ & $1 *$ & $1 *$ & $1 *$ & $1 *$ & $1^{*}$ & $1 *$ & 7 \\
\hline Ghavidel 1388 (35) & 1 & 1 & 1 & 1 & 1 & --- & 1 & 1 & 1 & 8 & --- & $1 *$ & $1^{*}$ & $1^{*}$ & $1 *$ & $1^{*}$ & --- & 5 \\
\hline Shams $1396(29)$ & 1 & 1 & 1 & 1 & 1 & --- & 1 & 1 & 1 & 8 & --- & $1 *$ & $1^{*}$ & $1^{*}$ & $1 *$ & $1 *$ & --- & 5 \\
\hline $\begin{array}{l}\text { Mohammadi } \\
1395(33)\end{array}$ & 1 & 1 & 1 & 1 & 1 & --- & 1 & 1 & 1 & 8 & --- & $1^{*}$ & $1^{*}$ & $1^{*}$ & $1^{*}$ & $1^{*}$ & --- & 5 \\
\hline $\begin{array}{l}\text { Mohammadi } \\
1385(18)\end{array}$ & 1 & 1 & 1 & 1 & 1 & --- & 1 & 1 & 1 & 8 & --- & $1^{*}$ & $1^{*}$ & $1^{*}$ & $1^{*}$ & $1^{*}$ & ---- & 5 \\
\hline Hassanali 1395 (34) & 1 & 1 & 1 & 1 & 1 & -.- & 1 & 1 & 1 & 8 & --- & $1^{*}$ & $1^{*}$ & $1^{*}$ & $1^{*}$ & $1^{*}$ & --- & 5 \\
\hline
\end{tabular}

Description of Scores of JADAD, Consort, and Newcastle-Ottawa Scales: The mean+SD of JADAD scale was $2.48 \pm 0.511$ with a minimum of 2 and a maximum of 3 . That of Consort was $5.43 \pm 0.662$ with a minimum of 5 , and a maximum of 7 and that of Newcastle-Ottawa was $8.00 \pm 0.00$ with a minimum and maximum of 8 .

The Correlation among the Scores of JADAD, Consort, and Newcastle-Ottawa Scales: The Spearman correlation coefficient between JADAD and Consort was not significant $(r=0.359, p=0.092)$. Also, the test could not be run for the correlation between the scores of Newcastle-Ottawa and the scores of the JADAD and Consort scales.

The Subgroup Comparison of Mean Scores of JADAD,
Consort, and Newcastle-Ottawa: The mean scores of the three scales were analyzed according to year. The years of publication of the papers were divided into 2006-2012, 2013-2014, 2015, 2016, and 2017, respectively. The Kruskal-Wallis test showed no significant difference in this regard between the Newcastle-Ottawa scale $(p=1.000)$, Consort $(p=0.424)$, and JADAD $(p=0.839)$. On the whole, the course of mean scores of the studies could be described as an ascending order with increasing years on the basis of the scores of JADAD and Consort scales, though this course has undergone some slight fluctuations at some points in time. This course is stable for the mean scores of the Newcastle-Ottawa scale (Fig. 4). The mean

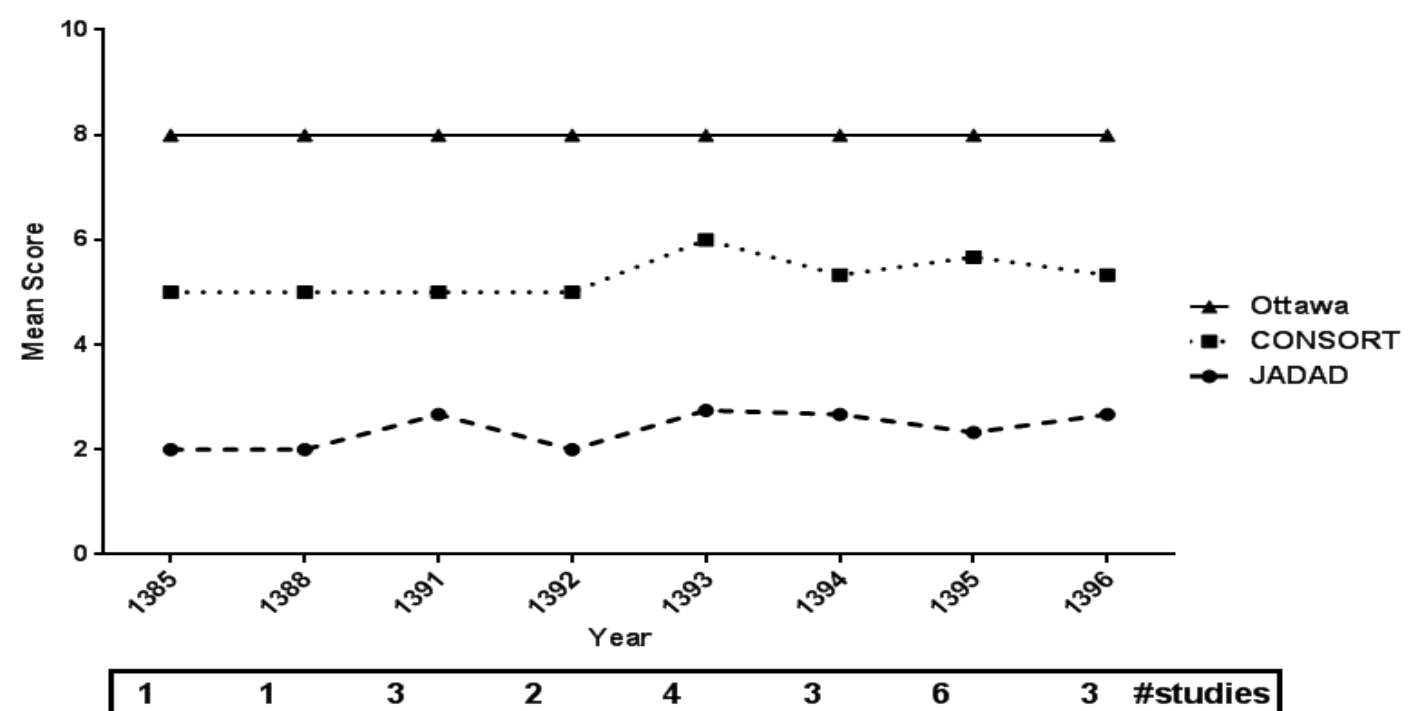

Fig. 4. The trend of annual changes in the mean scores of qualities of methodology of papers according to the measurement scale 
scores of the three mentioned scales were examined with respect to the presence of a model developer in the research team. The results of the U Mann-Whitney test suggested that the presence of a model developer in the research team induced no significant difference in the scores of JADAD $(p=0.259)$, Consort $(p=0.122)$, and NewcastleOttawa $(\mathrm{p}=1.000)$ scales.

The scores of the three scales were compared with respect to interpersonal cooperation (1-3 researchers, 4 researchers, 5 researchers, 6 researchers, 7 researchers, and more). The results of the Kruskal-Wallis test indicated no significant difference in this regard between the scores of JADAD $(p=0.262)$, Consort $(p=0.686)$, and NewcastleOttawa $(\mathrm{p}=1.000)$ scales. Moreover, the scores of JADAD, Consort, and Newcastle were compared according to inter-university cooperation (1 university, 2 universities, 3 universities, 4 universities, and more). It should be pointed out that the interuniversity cooperation was maximally among 6 universities. The results of the Kruskal-Wallis test demonstrated a significant difference in this regard between the scores of Consort $(p=0.036)$ and JADAD $(p=0.022)$; yet, this difference was not significant with the scores of Newcastle-Ottawa $(\mathrm{p}=1.000)$. Considering JADAD, the U Mann-Whitney test revealed a significant difference pertaining to 1 and 3 universities group $(p=0.014), 1$ and 4 universities group $(p=0.025), 2$ and 3 universities group $(\mathrm{p}=0.048)$, and 2 and 4 universities group ( $\mathrm{p}=0.079$ ); of course, the difference in 2 and 4 universities' group was close to the level of significance. Regarding the scores of the Consort scale, the results of the U Mann-Whitney test indicated that the significant difference pertained to 1 and 2 universities group $(p=0.014)$, and 1 and 3 universities group $(p=0.018)$. Regarding international cooperation, only two studies relating to one project $(34,40)$ used, in addition to Iranian scholars, researchers from Iraq and Canada to implement and evaluate the Partnership Care Model; of course, it was impossible to run a statistical test for this study. Furthermore, regarding the corresponding author's place of residence where the model was operationalized and implemented, 8 provinces could be mentioned among which Tehran Province had the greatest share (portion) (10 cases with $43.5 \%)$.

The shares of other provinces were: Ahvaz ( 2 cases with $8.7 \%$ ), Kerman (4 cases with $17.4 \%$ ), Shiraz (1 case with $4.3 \%$ ), Tabriz ( 2 cases with $8.7 \%$ ), Isfahan ( 2 cases with 8.7\%), Khorasan-e Jonoobi (Gonabad) (1 case with 4.3\%), and Khorasan Razavi (Sabzevar) (1 case with 4.3\%). The Kruskal-Wallis test showed that the type of province induced no significant difference in the mean scores of Consort $(p=0.130)$, Newcastle-Ottawa $(p=1.000)$, and JADAD $(p=0.072)$ scales, though the difference in JADAD scores was close to the level of significance.

\section{Discussion}

The number of journals and papers published in recent years in the field of medicine and allied health has increased dramatically and doubled in a short time (48). Along with advancements in medical sciences and an increased number of scientific medical journals, the struc- ture of the papers published in medical journals and their correspondence to reporting standards and research methods have been highlighted more than ever. Yet, a question that has not been fully answered is: Has the qualitative growth of research been the same as its quantitative growth? It is crystal-clear that the promotion of the quality of research would lead to the increased effect of their application in advancing various sciences since the low quality of research would bring about negative consequences resulting in inaccurate conclusions (49). Undoubtedly, observation of standards of research and reporting is necessary for improving the quality of the papers published by the native Iranian scholars. Randomized clinical trial is one type of study in which the subjects are randomly assigned to either the case or control group to compare the intended consequences. These studies are among the most valuable designs for assessing the efficacy of treatments regardless of whether the difference in results approaches the level of significance or not. Hence, it is important that these studies be done with high quality of research completion and reporting (13). The present study is a review of 16-year application of the Partnership Care Model with two goals: 1. Determining the effect of the Partnership Care Model on the consequences of chronic diseases, and 2. Describing and assessing the quality of methodology of the locally published papers. A total of 11509 papers were obtained in the primary search. Using the PRISMA screening guide, this number was reduced to 23 studies (Fig. 1).

The Patients under Study in the Chronic Diseases Population: As it can be observed in Table 2, the Partnership Care Model has exerted a significant positive effect on the consequences of chronic diseases in various populations of children, young children, teenagers, and adults. This significant effect on the consequences of various chronic disorders in different populations indicates a turning point and the lost circle of these diseases induced in patients and their family members by various personal, interpersonal, extra personal, and intra personal factors. This is because in this model, the patient, the family, the healthcare team, and all individuals involved in the patient's care will participate in the care process aiding in resolving many of the patient's problems. The patient's problem has nothing to do with the quality or quantity of the care; rather, they receive the best treatments and care. Their challenge is the continuation of treatment and care. So, the fundamental and fatal concept of partnership follow-up and care continuation of the patient unit may be applied in the dynamic and interactive care process between the nurse, the patient, and their family to control the disease and diminish its untoward sequelae. The art of Partnership Care Model is the linking and restoring of this lost circle since partnership care is a care philosophy that creates common goals for the care unit (patient care) and beyond the patient (self-care), the nurse (nursing care), or the physician (physician-centered care); this is because more than one person usually participate in a communicative process and the goal(s) is the same for all individuals. This philosophy warrants the common goal(s) provided that 1 . The goal(s) is recognized clearly and homogeneously by all mem- 
bers/patient units as a need and a necessity, 2. All individuals exert their best effort to reach the common goal(s), and 3. Reaching the goal(s) is rendered as the common fate of all individuals involved, and not just one individual (15). In this case, the patient unit is identified as the crux of all caregiving activities (49). Enabling and empowerment are the two basic concepts in the partnership care philosophy. Enabling refers to providing opportunities for all members to show their current capacities and competencies and to acquire new skills and abilities in line with the set goal(s). Empowerment, however, explains the professional interactions with families so that the family feels a sense of control over their life. Consequently, the family's abilities for performing health promotion activities to achieve the goal(s) are fostered (49). The practical goals of the Partnership Care Model are 1. Creation and establishment of an effective, continuous, and interactive relation among the healthcare team in the caregiving process, 2. Increasing cooperation, motivation, and responsibility among the healthcare team in the caregiving process, 3 . Promoting the health level and the quality of healthcare, 4 . Increasing patients' satisfaction with the quality of life, and 5. Decreasing side-effects, after-effects, and risk factors of the disease $(15,16)$. On the other hand, patient's treatment adherence and partnership among the healthcare team ought to be identified as the highly important components of the lost circle of various chronic disorders while the Partnership Care Model has the ability to link and restore the lost circle on the basis of the 23 reviewed studies (Table 2). Partnership is the mental and emotional engagement of the individuals including the client, the nurse, the physician, or other people in a teamwork process. Treatment adherence or compliance is the client's agreement, accompanying, and cooperation with or observation of the healthcare programs. Hence, the client's and the community's conscious and active compliance/adherence or partnership is the most important component of the partnership care process (Fig. 1). Lack of adherence to treatment means that individuals or clients do not cooperate in the treatment process despite their awareness of the presence of disease and health threat and of the necessity of observing ethical codes. This occurs due to a lack of the required awareness of or belief in the detrimental consequences or due to personal, familial, and social problems (15). The concepts of "non-adherence", "insufficient perception and lack of awareness of the nature of the disease", and "ineffective care relation" along with "concept and approach of partnership" form the fundament and skeleton of the Partnership Care Model (Fig. 1). On the whole, it could be postulated that partnership care is "the organized and logical process of establishing an effective, interactive, and dynamic relation between client (as partner) and healthcare providers (as participant) aimed at greater perception of needs, problems, and expectations in the disease control process and motivation and engagement of the clients to accept responsibility and to help improve, maintain, and promote their health (16).

Quality assessment scales of Papers: Assessment of the quality of randomized clinical trial reporting is a relatively important progressive area. Checklists, components, and scales are three instruments for assessing clinical trials. Components rely on just some aspects of trials; nevertheless, checklists and scales focus on a list of items in the assessment. In assessment, scales provide a numerical value of the quality of trial report that can be used in review studies (13). In the present study, JADAD, Consort, Newcastle-Ottawa, and Cochrane Risk of Bias scales were used to investigate the quality of study reports. This is because a good report enables the readers to achieve the judgment that the internal validity of the study is high and without statistical bias. Of course, it should be noted that the quality of a clinical trial differs from the quality of its report. The quality of a clinical trial is defined as having confidence in the clinical trial to compare the treatments with the least amount of errors in design, implementation, and analysis. Also, the quality of reporting of a clinical trial is defined as the high-quality report of information on the design, implementation, and analysis of the study. Therefore, an erroneous trial can be reported well and obtain a high score of report quality. On the contrary, a well-designed study with a poor report will receive a low score of report quality (50). Spearman correlation coefficient showed no significant correlation between the JADAD and Consort scales. Hence, it could be said that both JADAD and Consort can be used separately to survey the stability and quality of papers. The Spearman correlation coefficient test could not be run because the Newcastle-Ottawa scores of the 23 studies were the same. The mean of the scores of the three scales can be used instead. The mean score of JADAD was lower than that of the other two scales and the mean score of Consort was smaller than the mean score of Newcastle-Ottawa. The reason for the higher mean score of Newcastle-Ottawa than the other two scales may be attributed to the internal homogeneity of the items in this scale since there are some minimum criteria in interventional studies for selecting the case and control subjects. These minimal criteria are not only the convention and intrinsic nature of reporting of interventional studies, but also the authors oblige themselves to provide a comprehensive list of these items. This is less true with JADAD and Consort that examine items merely for methodology. This is the main reason for the lower mean scores of these two scales compared to Newcastle-Ottawa. The relatively ascending order of JADAD, Consort, and Newcastle-Ottawa in the course of time indicates that the knowledge on implementation and operationalization of this model has increased with increasing years from the inception and this increase has led to the ascending course of the scores of three scales of paper quality assessment, though, albeit, Kruskal-Wallis test indicated no significant difference in this regard. Inter-university cooperation was another factor that was significant in the subgroup analysis since contemplation and consultation in implementing research projects would lead to a synergism that promotes the quality of papers and improves both the quality and quantity of papers. As can be observed in Table 2, although the implementation of interventional studies using the Partnership Care Model is relatively good, the style of their reporting is poor (Tables $3 \& 4$ ). Thus, even though the reviewed studies be- 
long to the clinical trials, Newcastle-Ottawa was used along with JADAD, Consort, and Cochrane Risk of Bias to investigate the quality of their report, because clinical trials are highly similar to interventional cohort studies. These similarities are, in fact, the items in NewcastleOttawa (13). It should be mentioned that the low quality of reports of Persian and English articles is not something new as Moher et al. reported that the quality of reports of English clinical trial papers is similar to non-English papers (51). Other scholars reached similar conclusions like the following. DerSimonian et al. showed in their investigation of 67 clinical trials published during 1979-1980 that despite the fact that they had referred to random sampling in $84 \%$ of cases, only $19 \%$ elucidated the randomization procedures completely (52). Ayatollahi et al. assessed the quality of randomized controlled clinical trials published in Iranian medical journals during 2001-2003. Of 227 clinical trials published in 25 scientific-research journals in Iran, only $11.9 \%$ referred to single-blindness and $37.9 \%$ referred to double-blindness. The researchers concluded that the clinical trial papers published in Iranian medical journals do not enjoy either proper design or appropriate reporting style (53). Schulz et al. reported that of 206 randomized clinical trials, only $32 \%$ had stated the randomization method exactly (54). Pucock et al. examined 45 clinical trials published in 3 reputed medical journals and reported that merely $11.1 \%$ of the clinical trials referred to determining sample volume (55). Mosteller explored 147 cancer clinical trials and reported that only $25 \%$ of cases had mentioned the statistical tests and procedures used in these trials (56). Berwanger et al. surveyed the quality of abstracts of randomized controlled clinical trials published in 4 outstanding medical journals in 2006 using the Consort checklist. The researchers had expected to obtain better results than what they had actually obtained. They hope that the quality of abstracts would improve in future reports of abstracts (57). Dickinson et al. examined all 208 cerebral traumata clinical trials conducted before 1999 and showed that only 4\% of the trials enjoyed appropriate sample volume (58). Moreover, Zahed Pasha et al. investigated the level of observing medical ethics in clinical theses and dissertations in Babol University of Medical Sciences and demonstrated that only $40 \%$ of cases had referred to obtaining patients' informed consent for participation (59). Moher et al. (2002) examined complementary medicine clinical trials performed in pediatric populations and reported that almost $40 \%$ acquired the maximal score of JADAD (48). Burns et al. investigated the randomized controlled clinical trials on acute pulmonary injuries in five important databases. They reported that familiarizing the authors and reviewers with Consort checklist is of utmost importance and would result in promoted quality of reporting of abstracts of the studies (60). Altman et al. reviewed 80 clinical trials published during 1987-1988 and found that only $40 \%$ of the papers had referred to randomization (61).

\section{Conclusion}

Although the Partnership Care Model originated from a special background like hypertension and was primarily evaluated in this context, due to the common characteristics of patients with chronic diseases and considering the findings of the review of studies that used Partnership Care Model, also their positive effect on various consequences under study, and given its efficacy with various patients, different groups of children, teenagers, young people, and adults, it can be concluded that this local model that is consistent with the Iranian culture and texture, is an effective, simple, efficacious, and reliable model that can be used to promote and improve various aspects of chronic diseases; it can also be assessed and used in non-Iranian communities. A point neglected in the report of 23 studies that used the Partnership Care Model is the quality of the report of studies. Today, many efforts have been made to improve the quality of reports of clinical trials since the randomized clinical trials can affect the treatment of patients more than any other method. Consequently, their proper design and accurate report are of utmost significance. In an appropriate report of a clinical trial, it is necessary to provide comprehensive information on their designing, implementation, analysis, and interpretation since the readers and reviewers of a clinical trial should be aware of issues like the why and how of the trial and its analysis method to be able to identify its capabilities and limitations. Clinical trials with a weak methodology or with statistical bias may mislead physicians or negatively affect decision-makers in their policy-making. Inaccurate reporting of clinical findings may also mislead the healthcare system at all levels from policy-making for the public health to treating a patient. Hence, it is mandatory for scholars to do their best to publish their work with high quality and give an accurate report of the study as they did in the implementation of the study. Nevertheless, this model has not been applied to ICU/CCU patients despite its effectiveness, efficacy, usefulness, and simplicity. It is recommended that the model be applied and assessed in the ICU/CCU population. Moreover, the findings of the scales used to assess the quality of the study reports were not satisfactory though they were at the moderate to acceptable levels. It is recommended that along with the four dimensions of the Partnership Care Model including motivation, preparation, involvement (implementation), and assessment, the scales used to assess the quality of implementation and reporting of papers be considered since the four components were operationalized completely in all 23 reviewed papers; the results of the first dimension of Newcastle-Ottawa scale approves this point. Yet, the quality of the paper reports was not satisfactory. Thus, if the scales for implementing and assessing the study are aligned with model implementation, the quality of study implementation and the paper report will improve greatly. Another recommendation is to depict the intervention from the onset to the end to understand the implementation and the whole process of intervention more vividly and clearly. In this way, the beginner or even experienced scholars are not misled in implementing the clinical models. Unfortunately, even in the latest versions of assessment scales, no mention of drawing pictures is made, so, this study can serve as a good starting point for adding this important component to assessment scales used for evalu- 
ating the quality of paper publication or even implementation of studies.

\section{Acknowledgments}

The authors like to give their special thanks to Professor. Eisa Mohammadi, the developer of the Partnership Care Model who provided us with the full text of his Ph.D. dissertation. We would like to thank the Clinical Research Development Unit of Hamadan Besat Hospital, for cooperation and assistance throughout the period of study

\section{Conflict of Interests}

The authors declare that they have no competing interests.

\section{References}

1. Odunaiya N, Louw Q, Grimmer K. Are lifestyle cardiovascular disease risk factors associated with pre-hypertension in 15-18 years rural Nigerian youth? A cross sectional study. BMC Cardiovasc Disord. 2015;15(1):144.

2. Merai R. CDC grand rounds: a public health approach to detect and control hypertension. MMWR. 2016;65:1261.

3. Yoon SS, Fryar CD, Carroll MD. Hypertension prevalence and control among adults: United States, 2011-2014: US Department of Health and Human Services, Centers for Disease Control and Prevention, National Center for Health Statistics; 2015.

4. Haghdoust A, Sadeghirad B, Rezazadeh KM. Epidemiology and heterogeneity of hypertension in Iran: a systematic review. Arch Iran Med. 2008; 11(4):444-452.

5 Yazdanpanah L, Shahbazian H, Shahbazian H, Latifi SM. Prevalence, awareness and risk factors of hypertension in southwest of Iran. J Renal Inj Prev. 2015;4(2):51.

6. Farzadfar F, Murray CJ, Gakidou E, Bossert T, Namdaritabar H, Alikhani S, et al. Effectiveness of diabetes and hypertension management by rural primary health-care workers (Behvarz workers) in Iran: a nationally representative observational study. Lancet. 2012;379(9810):47-54.

7. Benjamin EJ, Virani SS, Callaway CW, Chang AR, Cheng S, Chiuve SE, et al. Heart Disease and Stroke Statistics-2018 Update: A Report From the American Heart Association. Circulation. 2018;137:e67e492.

8. Bashar FR, Vahedian-Azimi A, Mahmood Salesi SM, Zijoud H. The Effect of Progressive Muscle Relaxation on the Outcomes of Myocardial Infarction: Review Study. J Mil Med. 2017;19(4):326-35.

9. Khan A, Ramsey K, Ballard C, Armstrong E, Burchill LJ, Menashe V, et al. Limited Accuracy of Administrative Data for the Identification and Classification of Adult Congenital Heart Disease. J Am Heart Assoc. 2018;7(2):E007378.

10. Bisson A, Bodin A, Clementy N, Babuty D, Lip GY, Fauchier L. Prediction of Incident Atrial Fibrillation According to Gender in Patients with Ischemic Stroke From a Nationwide Cohort. Am J Cardiol. 2018; 121(4):437-444.

11. George MG, Tong X, Bowman BA. Prevalence of cardiovascular risk factors and strokes in younger adults. JAMA Neurol. 2017;74(6):695-703.

12. Hemmati MM, Merghati SZ, Didarloo A. Effectiveness of an educational intervention (based on basnef model) on lifestyle of patients with heart failure. Payesh. 2017;16(4):501-510.

13. Moosavinasab SMM, Vahedian-azimi A, Hosseini-Zijoud SM, Salesi M, Karimizarchi AA, KhoshFetrat M, et al. A Review of 17 Years of Application of a Continuous Care Model on the Consequences of Acute and Chronic Diseases: Describing and Assessing the Quality of Methodology of Papers. J Mil Med. 2018;20(1):27-55.

14. Bashar FR, Vahedian-Azimi A, Hajiesmaeili M, Salesi M, Farzanegan B, Shojaei S, et al. Post-ICU psychological morbidity in very long ICU stay patients with ARDS and delirium. J Crit Care. 2018;43:88-94.

15. Mohammadi E. Designing and Evaluation of Partnership Care Model on the control of high blood pressure PhD Dissertation, Tarbiat Modares Univesity, Nursing Department, School of Medical Sciences
2002.

16. Mohammadi E, Abedi HA, Gofranipour F, Jalali F. Partnership caring: A theory of high blood pressure control in Iranian hypertensives. Int J Nurs Pract 2002;8(6):324-329.

17. Hage AM, Lorensen M. A philosophical analysis of the concept empowerment; the fundament of an education-programme to the frail elderly. Nurs Philos. 2005;6(4):235-46.

18. Mohammadi E, Abedi HA, Jalali F, Gofranipour F, Kazemnejad A. Evaluation of 'partnership care model' in the control of hypertension. Int J Nurs Pract. 2006;12(3):153-9.

19. Moher D, Shamseer L, Clarke M, Ghersi D, Liberati A, Petticrew M, et al. Preferred reporting items for systematic review and metaanalysis protocols (PRISMA-P) 2015statement. Syst Rev. 2015;4(1):1.

20. Jadad AR, Moore RA, Carroll D, Jenkinson C, Reynolds DJM, Gavaghan DJ, et al. Assessing the quality of reports of randomized clinical trials: is blinding necessary? Control Clin Trials. 1996;17(1): $1-12$.

21. Altman DG, Schulz KF, Moher D. The revised CONSORT statement for reporting randomized trials: explanation and elaboration. Chinese J Evid-Based Med. 2005;5(9):712-4.

22. Higgins J, Green S. Cochrane handbook for systematic reviews of interventions Version 5.1. 0 [updated March 2011]. 2011, The Cochrane Collaboration. Available from www cochrane-handbook org. 2016.

23. Likis FE, Andrews JC, Fonnesbeck CJ, Hartmann KE, Jerome RN, Potter SA, et al. Smoking cessation interventions in pregnancy and postpartum care. Evid Rep Technol Assess. 2014.

24. Mohammadi E, Rezapour R, Sistanehei F. Evaluation of long-term care based on the partnership care model in quality-of-life and metabolic control of diabetic patients. J Am Sci. 2011;7(10):607-16.

25. Khoshab H, Bagheryan B, Abbaszadeh A, Mohammadi E, Kohan S The effect of partnership care model on depression and anxiety in the patients with heart failure. Evid Based Care. 2012;2(2):37-46.

26. Borhani F, Khoshab H, Abbaszadeh A, Rashidinejad $H$, Mohammadi E. Study of the effect of partnership care model on the quality of life in patients with heart failure. Iran J Crit Care Nurs. 2012; 5(1):43-48

27. Kashaninia Z, Rezasoltani P, Zinati F. The effect of partnership caring model on depression of adolescents with Major thalassemia. J Prev Health. 2016;1(2):69-82.

28. Zinati F, Khashaninia Z, Rahgoi A, Rezasoltani P, Babamahmodi F. The effect of partnership caring model on quality of life of adolescents withmajor thalassemia. Iran $J$ Rehabil Res Nurs. 2016;2(2):57-67.

29. Shamsi A, Amiri F, Ebadi A, Ghaderi M. The Effect of Partnership Care Model on Mental Health of Patients with Thalassemia Major. Depress Res Treat. 2017;2017.

30. Borji M, Motaghi M. The Effect of Collaborative CareModel on Social Support and General Self-Efficacy of the Elderly. J Nurs Educ. 2017;5(1):22-9.

31. Zare Shorakie H, Pishgooie SAH, Zareiyan A, Atashzade Shooride F. The Effect of the Collaborative Care Model Implementation on Quality of Life in Patients with Heart Diseases. Mil Caring Sci. 2017;4(1):39-48

32. Sajjadi M, Tavakolizadeh J, Heidary Marghzar M. Effect of the Intervention based on Partnership Care Model on Self-Concept Promotion in Patients with Type II Diabetes. Horizon Med Sci. 2017;23(1):41-7.

33. Mohammadi E, Khoshab HM, Kazemnejad AP. Activities of daily living for patients with chronic heart failure: a partnership care model evaluation. Appl Nurs Res. 2016 May 2016;30:261.

34. Hassanali G, Kermanshahi SMK, Kakil D, Mordoch E. The Effect of Partnership Care Plan on Metabolic Control ofIraqi Diabetic Adolescents. J Diabetes Metab. 2016 May;7(5).

35. Ghavidel F, Mohammadzadeh S, Pirasteh H, Alavi Majd H. Effect assessment of applying the partnership care model on quality of life in hemodialysis patients reffering to Be'sat Hospital of IRI Air Force. Ebnesina. 2009;12(2):22-7.

36. Martínez-Mesa J, González-Chica DA, Duquia RP, Bonamigo RR, Bastos JL. Sampling: how to select participants in my research study? An Bras Dermatol. 2016;91(3):326-30.

37. Alijany-Renany H, Tamaddoni A, Haghighy-zadeh M, Pourhosein $\mathrm{S}$. The effect of using partnership care model on the quality of life in the school-age children with $\beta$-thalassemia. J Shahrekord Univ Med 
Sci. 2012;14(1):41-9.

38. Parviniannasab A, Rosta S, Vojdani M, Dehghani A, Keshtkaran Z, Shamsizade $M$, et al. The effect of partnership care Model on depression of adolescents with $\beta$-thalassemia. Iran J Psychiatr Nurs. 2014;1(4):25-35.

39. Daneshi F, Sabzevari S, Pooraboli B, ShojaeiShahrokhababdi M. The effect of partnership care model on the quality of life of adults with Asthma. Iran J Nurs. 2014;27(88):1-10.

40. Hassanali G, Mohammad Khan Kermanshahi S, Anvar Kakil D. The effect of partnership caring model on diabetic adolescence'metabolic control referring to diabetes center of Arbil city. Evid Based Care. 2014;3(4):59-64.

41. Mamene M, Lakdizaji S, Rahmani A, Behshid M. The effect of education based on the collaborative care model on the nutritional behaviors of family members of patients with type II diabetes. Medsurg Nurs J. 2014;3(2):99-106.

42. Lashkari F, Brazparandjani S, Latifi SM, Chahkhoei M, Khalili A, Paymard A, et al. The effect of collaborative care model on the fatigue in patients undergoing maintenance hemodialysis: A randomized clinical trial. Qom Univ Med Sci J. 2016; 10(8):71-79.

43. Parastoo R, Mohsen S, Mahin M, Hamid S. Evaluation of the effect of collaborative care on depression, anxiety and stress of patients after coronary angioplasty. Medsurg Nurs J. 2016;5(2):59-66.

44. Alamdarloo A, Hosseini M, Reza K, Noroozi K, Reza Soltani P, Mazki S. The effect of collaborative care model on sleep quality of patients' undergoing Coronary Artery Bypass Graft Surgery. Iran J Rehabil Res Nurs. 2015;1(4):49-59.

45. Nayyeri S, Golafrooz M, Sadaghi H, Amini S, Zarrabi L, Rakhshani M. The effect of the partnership care model on the quality of sleep among patients with heart failure. J Sabzevar Uni Med Sci. 2015;22(2):289-99.

46. Nouhi E, Karbalaizadeh M, Abazari F. The effect of mothers' participation and the family-centered care on mother's anxiety with children suffering from gastrointestinal infections: a randomized clinical trial. J Clin Nurs Midwif. 2015;4(3): 47-55.

47. Mamene M, Lakdizaji S, Rahmani A, Behshid M. The Effect of Teaching Based Collaborative Care Model on Diet Habits in Diabetes Type II: a clinical trial study. Sci J Hamadan Nurs Midwif Fac. 2014;22(1):41-51.

48. Moher D, Sampson M, Campbell K, Beckner W, Lepage L, Gaboury I, et al. Assessing the quality of reports of randomized trials in pediatric complementary and alternative medicine. BMC Pediatr. 2002;2(1):2.

49. Chung W, Lee KW, Hwang IH, Lee DH, Kim SY. Quality assessment of randomized controlled trials in the Journal of the Korean Academy of Family Medicine. Korean J Fam Med. 2009;30(8):626-31.

50. Moher D, Jadad AR, Nichol G, Penman M, Tugwell P, Walsh S. Assessing the quality of randomizedcontrolled trials: an annotated bibliography of scales and checklists. Control Clin Trials. 1995;16(1):62-73.

51. Moher D, Fortin P, Jadad AR, Jüni P, Klassen T, Le Lorier J, et al. Completeness of reporting of trials published in languages otherthan English:implications for conduct and reporting of systematic reviews. Lancet. 1996;347(8998):363-6.

52. DerSimonian R, Charette LJ, McPeek B, Mosteller F. Reporting on methods in clinical trials. N Engl J Med. 1982;306(22):1337-2.

53. Ayatollahi M, Jafari P, Ghaem H. Assessment of Quality randomized controlled trials published in Iran during 2000-2002. Babol Univ Med J. 2004;7(4):64-70.

54. Schulz KF, Chalmers I, Grimes DA, Altman DG. Assessing the quality of randomization from reports of controlled trials published in obstetrics and gynecology journals. JAMA. 1994;272(2):125-8.

55. Pocock SJ, Hughes MD, Lee RJ. Statistical problems in the reporting of clinical trials. N Engl J Med. 1987;17(7):426-432.

56. Mosteller F, Gilbert JP, McPeek B. Reporting standards and research strategies for controlled trials: agenda for the editor. Control Clin Trials. 1980;1(1):37-58.

57. Berwanger O, Ribeiro RA, Finkelsztejn A, Watanabe M, Suzumura EA, Duncan BB, et al. The quality of reporting of trial abstracts is suboptimal: survey of major general medical journals. J Clin Epidemiol. 2009;62(4):387-92.

58. Dickinson K, Bunn F, Wentz R, Edwards P, Roberts I. Size and quality of randomised controlled trials in head injury: review of published studies. BMJ. 2000;320(7245):1308-11.
59. Zahed Py HR, Riahi H. Medical ethics in theses and clinical trials in Babol University of Medical Sciences. J Babol Univ Med Sci. 2003; 5(3): 45-51.

60. Burns KE, Adhikari NK, Kho M, Meade MO, Patel RV, Sinuff T, et al. Abstract reporting in randomized clinical trials of acute lung injury: an audit and assessment of a quality of reporting score. Crit Care Med. 2005;33(9):1937-45.

61. Altman DG, Schulz KF, Moher D. Turning a blind eye: testing the success of blinding and the CONSORT statement. BMJ. 2004;328(7448):1135. 